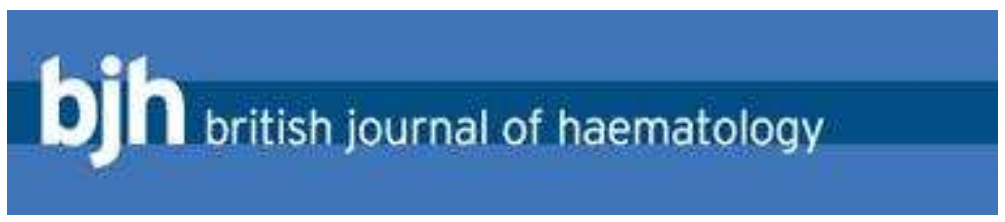

\title{
Mild hemorheological changes induced by a moderate endurance exercise in patients with sickle cell anemia
}

\begin{tabular}{|c|c|}
\hline Journal: & British Journal of Haematology \\
\hline Manuscript ID: & BJH-2010-02006.R1 \\
\hline Manuscript Type: & Ordinary Papers \\
\hline $\begin{array}{r}\text { Date Submitted by the } \\
\text { Author: }\end{array}$ & 24-Mar-2011 \\
\hline Complete List of Authors: & $\begin{array}{l}\text { Balayssac-Siransy, Edwige; Unité de Formation et de Recherche en } \\
\text { Sciences Médicales, Laboratoire de Physiologie et d'Explorations } \\
\text { Fonctionnelles } \\
\text { Connes, Philippe; Université Antilles-Guyane, UMR Inserm } 763 \\
\text { Tuo, Nalourgo; Unité de Formation et de Recherche en Sciences } \\
\text { Médicales, Laboratoire de Physiologie et d'Explorations } \\
\text { Fonctionnelles } \\
\text { Danho, Clotaire; Centre Hospitalier et Universitaire de Yopougon, } \\
\text { Service d'Hématologie clinique } \\
\text { Diaw, Mor; Faculté de Médecine et de Pharmacie, Laboratoire de } \\
\text { Physiologie } \\
\text { Sanogo, Ibrahima; Centre Hospitalier et Universitaire de Yopougon, } \\
\text { Service d'Hématologie clinique } \\
\text { Hardy-Dessources, Marie-Dominique; UAG, UMR Inserm } 763 \\
\text { Samb, Abdoulaye; Faculté de Médecine et de Pharmacie, } \\
\text { Laboratoire de Physiologie } \\
\text { Ballas, Samir; Thomas Jefferson University, Medicine } \\
\text { Bogui, Pascal; Unité de Formation et de Recherche en Sciences } \\
\text { Médicales, Laboratoire de Physiologie et d'Explorations } \\
\text { Fonctionnelles }\end{array}$ \\
\hline Key Words: & SICKLE CELL ANAEMIA, SICKLE, SICKLE CELL DISEASE \\
\hline
\end{tabular}


Mild hemorheological changes induced by a moderate endurance exercise in patients with sickle cell anemia

Edwige Balayssac-Siransy ${ }^{\mathrm{a}}$, Philippe Connes ${ }^{\mathrm{b}, \mathrm{c}}$, Nalourgo Tuo ${ }^{\mathrm{a}}$, Clotaire Danho ${ }^{\mathrm{d}}$, Mor Diaw ${ }^{\mathrm{e}}$, Ibrahima Sanogo $^{\mathrm{d}}$, Marie-Dominique Hardy-Dessources ${ }^{\mathrm{c}}$, Abdoulaye Samb ${ }^{\mathrm{e}}$, Samir K Ballas ${ }^{\mathrm{f}}$ and Pascal Bogui ${ }^{\mathrm{a}}$

${ }^{a}$ Laboratoire de Physiologie et d'Explorations Fonctionnelles, Unité de Formation et de Recherche en Sciences Médicales, Université de Cocody, Abidjan, Côte d'Ivoire

${ }^{b}$ Laboratoire ACTES (EA 3596), Département de Physiologie, Université des Antilles et de la Guyane, Pointe-à-Pitre, Guadeloupe

${ }^{c}$ Inserm U763, Pointe-à-Pitre, F-97159 Guadeloupe, Université des Antilles et de la Guyane, Pointe-à-Pitre, F-97157, Guadeloupe

${ }^{d}$ Service d'Hématologie clinique, Centre Hospitalier et Universitaire de Yopougon, Abidjan, Côte d'Ivoire

${ }^{e}$ Laboratoire de Physiologie, Faculté de Médecine et de Pharmacie, Université Cheikh Anta Diop, Dakar, Sénégal

${ }^{f}$ Cardeza Foundation for Hematologic Research, Department of Medicine, Thomas Jefferson University, Philadelphia PA, USA.

Running title: Blood rheology and homozygous sickle cell disease.

\section{Corresponding author:}

Philippe Connes, $\mathrm{PhD}$

Laboratoire ACTES (EA 3596), Département de Physiologie, Université des Antilles et de la Guyane, Pointe-à-Pitre, Guadeloupe; Email: pconnes@yahoo.fr 


\begin{abstract}
The levels and duration of physical activity that can be considered as completely safe in patients with sickle cell anemia (SCA) is unknown. The present study compared the hemorheological and hematological profile, cell density distribution and basic biochemistry between a group of 17 patients with SCA and 21 healthy subjects before and after a 20 min duration submaximal cycling exercise at the same absolute workload. Blood was sampled at rest and 3 min after the end of exercise for measurement of biological parameters. Exercise did not affect the hematocrit and blood viscosity in the two groups. Plasma viscosity was not different between the two groups at rest and similarly increased with exercise. The proportion of intermediary dense cells (with density between 1.11 and $1.12 \mathrm{~g} / \mathrm{ml}$ ) decreased with exercise in the SCA group resulting in an increase in the proportion of red blood cells with a density $>$ $1.12 \mathrm{~g} / \mathrm{ml}$. No change was observed in the control group. The present study suggests that mild-moderate exercise is not very harmful for SCA patients. The hemorheological and hematological changes very mild, except for the formation of dense cells but no clinically significant signs of medical complication were present in any of the patients.
\end{abstract}

Key words: Sickle cell anemia, dense cells, blood viscosity 


\section{Introduction}

Although regular physical activity has been shown to reduce the morbidity and mortality from many chronic diseases [metabolic syndrome and diabetes (Balducci et al, 2009, Colberg \& Grieco 2009), heart failure (Dubach et al, 2001), rheumatoid arthritis (Hurkmans et al, 2009), renal disease (Kouidi 2001), asthma (Welsh et al, 2005), clinical depression (Craft \& Perna 2004)], there is uncertainty as to whether patients with sickle cell anemia (SCA) should participate safely in a physical activity (Connes et al, 2010). Although laboratory exercise tests are more and more used by physicians to assess the cardio-respiratory responses and clinical severity of patients with SCA (Alameri et al, 2008, Anthi et al, 2007, Callahan et al, 2002, Delclaux et al, 2005, Sylvester et al, 2007) or to investigate the benefits of various medical interventions on SCA clinical expression (Hackney et al, 1997, Machado et al, 2005, Miller et al, 1980), very few studies focused on the potential benefits of exercise therapy in SCA.

The dilemma faced by health care professionals involved in SCA management is the level of physical activity (at work or in sport practice) they should recommend for their patients, in order to avoid potential complications (Connes et al, 2010). The presence of anemia is responsible for a reduction of oxygen delivery to tissues (Lonsdorfer et al, 1983) and faster transition from aerobic to anaerobic metabolism during exercise (Moheeb et al, 2007), which may stimulate the polymerization of hemoglobin $\mathrm{S}(\mathrm{HbS})$, lead to red blood cells (RBCs) sickling and promote microvascular occlusions. In addition, it has been reported that vigourous exercise in patients with SCA may lead to sporadic hemoglobinuria (Platt 1982), massive splenic infarction (Jama et al, 2002) or a worsening (if present) of pulmonary hypertension (Machado et al, 2007).

However it has been observed that exercise therapy consisting of moderate strength and endurance exercise of $10-30$ min duration may contribute to a reduction in the length of 
hospitalization in SCA children with vaso-occlusive crises (Alcorn et al, 1984). But such experiences are scarce because the levels and duration of physical activity that can be considered as completely safe in SCA patients is unknown. Before the establishment of accurate exercise program in SCA, there is a need to test the exercise type that SCA patients could be able to sustain without any risks of vaso-occlusive and medical complication. To fill part of the gap in this field, the present study was conducted to test the effect of a mildmoderate endurance exercise of 20 min duration (an exercise bout that mimics a very common and daily physical activity of healthy subjects/workers) on several biomarkers of increased risk for vaso-occlusives events. This approach has already been extensively used in asymptomatic heterozygous carriers (sickle cell trait carrier) to better understand the putative causes of exercise-related adverse event in that population (Connes et al, 2008). Most of the studies performed in sickle cell trait carrier demonstrated an abnormal response of blood rheology during prolonged intense endurance exercise or strenuous exercise, such as a large increase in blood viscosity (Tripette et al, 2010, Tripette et al, 2007) that could participate in microcirculatory impairment (Connes 2010). Since exercise intensity may be very problematic in SCA patients, the exercise intensity was set at $43 \pm 6 \mathrm{~W}$ and can be qualified as mild to moderate (Lonsdorfer et al, 1983). It corresponds to 3-4 metabolic equivalents (METs) and is closed to the energy expenditure of working activities such as masonry or carrying medium to heavy load. We compared the blood rheological profile, cell density distribution and basic biochemical and hematological parameters between a group of SCA patients and a group of healthy subjects before and after the submaximal exercise bout. 


\section{Methods}

\section{Patients}

Seventeen male patients with SCA (age: $25 \pm 3$ yrs, weight: $56 \pm 7 \mathrm{~kg}$, height: $172 \pm 6 \mathrm{~cm}$, HbS: $87.5 \pm 6.3 \%$ and fetal $\mathrm{Hb}: 9.9 \pm 6.5 \%$ ) and a control group composed of 21 sedentary male with normal $\mathrm{HbA}$ (age: $22 \pm 1 \mathrm{yrs}$, weight: $61 \pm 7 \mathrm{~kg}$ and height $172 \pm 6 \mathrm{~cm}$ ) were enrolled in the present study. Body weight was assessed to the nearest $0.5 \mathrm{~kg}$ using a set of balance scales. The patients were clothed, wearing a pair of shorts and socks but no shoes or shirts when body weight was measured. Height measurement was recorded to the nearest 0.5 $\mathrm{cm}$ for each patient and measurements were taken while the patient was holding a full breath in. All patients were in their steady state condition at the time of the study and none of them had been transfused or in crisis for at least 90 days prior to enrollment. SCA participants were randomly selected among steady-state SCA patients who came within the last six months in the Sickle Cell Center of Abidjan and met the inclusion criteria. No patient from the present study was on hydroxyurea therapy. Because alpha-thalassemia is known to widely modulate blood rheology in SCA (Ballas et al, 1988, Serjeant et al, 1983), patients with alpha gene deletion were excluded from the study. Alpha globin genotypes were determined according to published methods (Chong et al, 2000). Before enrollment, all patients and control subjects had clinical examination and underwent resting electrocardiography (ECG), echocardiography and spirometry to check for the absence of severe exercise cons indication. Data are provided in the table 1. All subjects provided informed consent and the ethics committee of the Academic Hospitals of Yopougon (Abidjan, Ivory Coast) approved the study in accordance with the guidelines set by the Declaration of Helsinki. 


\section{Exercise protocol}

The two groups were submitted to a classical symptom limited incremental exercise test. Finger pulse oxymetry, arterial pressure measurements, spirometry and electrocardiography were used for clinical monitoring. Cycling exercise test in supine position consisted of 4 min warm-up at $20 \mathrm{~W}$ in SCA patients and $40 \mathrm{~W}$ in controls, and then the load was increased by $0.15 \mathrm{~W} / \mathrm{kg}$ body weight and $0.3 \mathrm{~W} / \mathrm{kg}$ body weight every two minutes in SCA and control group, respectively, until volitional exhaustion. The peak power (Ppeak), peak ventilation (VEpeak) and peak heart rate were determined. On a second occasion, the two groups were submitted to a submaximal exercise bout in supine position consisting of 20 min duration at the same absolute workload (43 $\pm 6 \mathrm{~W})$ that corresponded to $48 \pm 1 \%$ and $30 \pm 1 \%$ of the Ppeak reached by the SCA and control group, respectively. Finger pulse oxymetry, arterial pressure measurements, spirometry and electrocardiogram were used for clinical survey. Oxygen saturation, heart rate, ventilation, systolic and diastolic arterial pressure values are reported. Dynamic ventilation response (VE kinetic) during exercise was modeled using previously validated exponential equation (Casaburi et al, 1989, Keslacy et al, 2008).

The general model comprising one or two components was the following:

$\mathrm{VE}(t)=\mathrm{VE}(\mathrm{BL})+\mathrm{A}_{\mathrm{F}} \cdot\left[1-\mathrm{e}^{-\left(t-\mathrm{TD}_{\mathrm{F}}\right) / \tau_{\mathrm{F}}}\right]+\mathrm{A}_{\mathrm{S}} \cdot\left[1-\mathrm{e}^{-\left(t-\mathrm{TD}_{\mathrm{S}}\right) / \tau_{\mathrm{S}}}\right]$

where $t$ is time (s), $\mathrm{VE}(\mathrm{BL})$ is the baseline $\mathrm{VE}$ before starting the exercise $(\mathrm{ml} / \mathrm{min}), \mathrm{A}_{\mathrm{F}}$ and $\mathrm{A}_{\mathrm{S}}$ are the increases at time $t$ in the amplitude of $\mathrm{VE}(1 / \mathrm{min}), \mathrm{TD}_{\mathrm{F}}$ and $\mathrm{TD}_{\mathrm{S}}$ are the time delay (s), and $\tau_{\mathrm{F}}$ and $\tau_{\mathrm{S}}$ are the time constant (s) for the first and second phases, respectively.

Blood was sampled into heparin, EDTA and dry tubes for biological measurements at rest and at the end of exercise ( $3^{\text {rd }}$ minute of recovery). An additional blood sample was taken at 20 minutes recovery for hematocrit and hemorheological measurements only. 


\section{Hemorheology and hematology}

Hemorheological parameters were measured immediately after sampling. Measurements of blood viscosity $(\eta b)$ and plasma viscosity $(\eta p)$ were performed with a cone plate viscometer (Brookfield DVII+, with CPE40 spindle) at $37^{\circ} \mathrm{C}$. Blood viscosity was determined at a shear rate of 45 and $90 \mathrm{~s}^{-1}$, and at both native hematocrit (uncorrected $\eta \mathrm{b}$ ) and corrected hematocrit (i.e. after adjustment of hematocrit at 40\%). The measurement of $\eta p$ was performed at $1500 \mathrm{~s}^{-}$

1. Hemorheological measurements were performed according to the recent guidelines for hemorheological laboratory techniques (Baskurt et al, 2009). Automated hematology analyzer (Max M-retic, Coulter, USA) was used for hemoglobin concentration ( $\mathrm{Hb}$ ), red blood cell (RBC), white blood cell (WBC) and platelet (PLT) count, mean cell volume (MCV) and mean corpuscular hemoglobin concentration (MCHC). Hematocrit (Hct) was measured after blood microcentrifugation (JOUAN-HEMA-C, Saint Herblain, France).

In addition, the index of red blood cell rigidity used by Dintenfass (Dintenfass 1985) was calculated according to the following equation and at a shear rate of $350 \mathrm{~s}^{-1}$ :

$\mathrm{Tk}=\left(\eta_{\mathrm{r}}^{0.4}-1\right) /\left(\eta_{\mathrm{r}}^{0.4} * \mathrm{Hct}\right)$

with $\eta_{\mathrm{r}}$ corresponding to the relative blood viscosity; i.e., the ratio $\eta \mathrm{b} / \eta p$.

\section{Red blood cell density}

Density distribution of RBCs was obtained using phthalate esters in microhematocrit tubes (Danon \& Marikovsky 1964). Briefly, mixtures of dibutyl and diethyl phthalate esters were prepared to give a range of twelve densities between 1.075 and $1.14 \mathrm{~g} / \mathrm{mL}$. Hematocrit tubes 
were filled with $30 \mu \mathrm{L}$ cell suspension and $10 \mu \mathrm{L}$ different phthalate solutions. Tubes were centrifuged at $12200 \mathrm{rpm}$ for 10 minutes at room temperature. The proportion of intermediary dense cells comprised in the following range of $(\geq 1.11 \mathrm{~g} / \mathrm{ml} ; \leq 1.12 \mathrm{~g} / \mathrm{ml})$ was measured as well as the proportion of cells with densities $>1.12 \mathrm{~g} / \mathrm{mL}$ usually reflecting the percent of irreversibly sickle cells (ISC) (Durpes et al, 2010).

\section{Biochemistry}

Plasma sodium $\left(\mathrm{Na}^{+}\right)$and potassium $\left(\mathrm{K}^{+}\right)$concentrations were measured with an electrolyte analyzer (flame photometer FP 20, SEAC, Italy). Routine coagulation measurements were performed on a coagulation analyzer (Biomerieux option 4, Switzerland) using proprietary reagents for prothrombin time, activated partial thromboplastin time and fibrinogen testing. A small drop of blood was also taken from a finger for blood lactate concentration determination (lactate pro analyser, Arkray, Japon)

\section{Statistics}

Data are expressed as means \pm standard deviation (SD). Peak exercise responses were compared between the two groups using an unpaired student $t$ test. The pre- and post-exercise biological data, as well as the exercise responses during the submaximal bout, were compared between the two groups using a two-way analysis of variance (ANOVA) with repeated measures. Pair-wise contrasts were used when necessary to locate where significant differences occurred. The significance level was defined as $p<0.05$. Analyses were conducted using Statistica (v. 5.5, Statsoft, Tulsa, OK, USA). 


\section{Results}

Baseline cardiac and spirometric parameters

Data are reported in the table 1 . The forced vital capacity, forced expiratory volume in one second and peak expiratory flow were lower in SCA group than in the control group. Mean tiffeneau index was greater than $80 \%$ in both groups and no difference was observed between them. The forced expiratory flow $25-75 \%$ was not different between the groups. One control subject only exhibited abnormal spirometry with a pattern characteristic of minor central obstructive syndrome. In the SCA group, 7 patients had a pulmonary restrictive syndrome and one had a distal pulmonary obstruction. Heart rate measured in supine position did not differ between SCA patients and the control group but stroke volume was greater in the former population. As a consequence, the SCA group exhibited higher cardiac index than the control group. One SCA patient had a coronary sinus rhythm and another one had repolarization abnormality in the inferior leads (T waves inversion). None of the other SCA patients or control subjects exhibited ECG abnormalities.

\section{Exercise responses}

Symptom limited incremental exercise test

The peak power (Ppeak) reached by SCA patients $(84.1 \pm 10.8 \mathrm{~W} ; 1.50 \pm 0.19 \mathrm{~W} / \mathrm{kg})$ was lower than in the control group $(150 \pm 16 \mathrm{~W} ; 2.45 \pm 0.28 \mathrm{~W} / \mathrm{kg})(\mathrm{p}<0.001)$. Peak ventilation (VEpeak) reached was lower in SCA group (47 \pm 10 1/min) than in the control group (84 \pm 14 $1 / \mathrm{min})(\mathrm{p}<0.001)$. The peak heart rate was $160 \pm 12 \mathrm{bpm}$ and $175 \pm 16 \mathrm{bpm}$ in SCA and control group, respectively $(\mathrm{p}<0.01)$.

Submaximal exercise test

Although a little bit higher in SCA patients, resting heart rate was not significantly different between the two groups at that time. With exercise, heart rate increased in the two groups but 
the increase was higher in SCA group. SCA patients exhibited higher heart rate during exercise and the first minutes of recovery (figure 1). Mean resting $\mathrm{SpO}_{2}$ of SCA patients $(92 \pm$ 4\%) was below the control values $(98 \pm 1 \%)$. Exercise did not change $\mathrm{SpO}_{2}$ in the two groups and thus, the values still remained lower in SCA group $(91 \pm 5 \%$ and $98 \pm 1 \%$ at the end of exercise in the SCA group and control group, respectively).

At rest, no difference was observed between the two groups for systolic pressure $(119 \pm 9$ $\mathrm{mmHg}$ and $119 \pm 5 \mathrm{mmHg}$ in the SCA group and control group, respectively). In contrast, resting diastolic pressure of SCA patients $(75 \pm 8 \mathrm{mmHg})$ was lower than control group (80 \pm $6 \mathrm{mmHg})(\mathrm{p}<0.05)$. Both systolic and diastolic pressures were above baseline values during exercise and the first minutes of recovery in the two groups (data not shown, $\mathrm{p}<0.001$ ). While systolic pressure remained not different between the two groups during exercise, the SCA group still exhibited lower values for diastolic pressure than control group during the effort (data not shown, $\mathrm{p}<0.01$ ).

Ventilation at rest was not different between the two groups (figure 2). Ventilation increased similarly with exercise in both groups until the $6^{\text {th }}$ minute of exercise. Then ventilation seems to be stabilized in the control group whereas it continues rising in the SCA group with the latter exhibiting greater values than the control group from the $7^{\text {th }}$ minute of exercise to the end of recovery.

VE kinetic was modeled using a first-order exponential model for the control group whereas a second-order exponential model was necessary for the VE kinetic modeling of the SCA group indicating the presence of a second phase. Mathematical modeling of VE demonstrated that first phase of VE did not differ between the two groups with $A_{F}$ and $\tau_{F}$ being very closed (mean $\mathrm{A}_{\mathrm{F}}=24.73$ and $26.99 \mathrm{l} / \mathrm{min}$, and mean $\tau_{\mathrm{F}}=73 \mathrm{~s}$ and $79 \mathrm{~s}$, in the control group and SCA group, respectively). After this first phase, the control group was well adapted and reached a VE plateau confirming that VE was stabilized. In contrast, the SCA group exhibited a second 
phase with no plateau $\left(A_{S}=3.01 / \mathrm{min}\right)$. The $\mathrm{VE}$ reached at the end of the 20 minutes exercise was $63 \%$ and $29 \%$ of VEpeak in the SCA and control group, respectively.

\section{Hemorheology, hematology and red blood cell density}

SCA patients were characterized by low $\mathrm{Hb}$ level, low Hct and low RBC number (table 2). Exercise did not change any of these two parameters in the two groups. As a consequence, SCA group exhibited lower uncorrected $\eta b$ (table 2), at any time. Exercise did not significantly change uncorrected $\eta \mathrm{b}$ in SCA patients. When corrected for Hct, corrected $\eta \mathrm{b}$ was significantly higher in SCA group than in the control group at any time and exercise did not induce significant change. Exercise significantly increased $\eta p$ above resting value but no difference was observed between the two groups at any time. Then $\eta p$ returned to baseline in the two groups. The index of RBC rigidity (Tk) was significantly greater in SCA group than in the control group at any time (Table 2). Exercise did not significantly affect Tk in any of the two groups. Higher level of WBC and PLT was observed in SCA patients both at rest and the end of exercise (Table 2). While PLT count did not change significantly with exercise, WBC count exhibited a slight but significant increase above baseline in SCA patients. MCV and MCHC were not statistically different between the two groups and did not change with exercise (Table 2).

Nevertheless, the study of the red blood cell density distribution for both groups shown that SCA patients exhibited significantly greater proportion of intermediary dense cells than control group at rest $(\mathrm{p}<0.001$; table 2$)$. Exercise had no effect in the control group but decreased the proportion of intermediary dense cells in SCA patients $(-8 \%)$. The difference between the two groups at the end of exercise did not reach statistical significance $(p=0.1)$. The percentage of cells with density higher than 1.12 was low in the control group $(0.4 \%)$ and was not modified with exercise. In contrast, the proportion of cells with a density higher than 
1.12 , generally reflecting the ISC population, was around $11 \%$ in the SCA group at rest and significantly increased to higher values with exercise $(+7 \%)(\mathrm{p}<0.01$; table 1$)$.

\section{Biochemistry}

The results are summarized in the table 3. Both groups exhibited no difference in the plasma level of $\mathrm{K}^{+}$or fibrinogen, as well as for the activated partial thromboplastin time (data not shown) or the prothrombin time. The higher $\mathrm{Na}^{+}$level at rest in SCA is not clinically meaningful. Blood lactate concentration was not different between the two groups at rest. Whereas exercise did not affect blood lactate level in the control group, it increases it in SCA patients leading this group to exhibit significantly greater values than control group after exercise $(\mathrm{p}<0.01)$. 


\section{Discussion}

The acute painful vaso-occlusive crisis is the major clinical manifestation of SCA. The initial patho-physiologic mechanisms of vaso-occlusion seem to involve several interacting key factors such as impaired blood rheology (Ballas \& Mohandas 2004, Tripette et al, 2009), marked pro-inflammatory vascular environment with abnormally adherent sickle cells, neutrophils and monocytes (Belcher et al, 2000, Hebbel 1997, Okpala et al, 2002), coagulation abnormalities (Key et al, 1998) and important endothelial dysfunction related to decreased nitric oxide bio-availability (Gladwin et al, 2003).

All baseline hematological and biochemical data of SCA patients are comparable to the hematological data usually found in sickle cell patients with no associated alpha-thalassemia (Serjeant \& Serjeant 2001). Thrombocytosis and leucocytosis was also found in the SCA group, as it has been previously described in this disease (Kenny et al, 1980, Leslie et al, 1975). Resting blood rheological values of our SCA group were also very closed to the values previously reported (Tripette et al, 2009). Spirometric results were in accordance with previous studies showing that patients with SCA have often reduced FVC, FEV1 and PEF (Pianosi et al, 1993, Young et al, 1988). Seven (41\%) SCA patients were found to have restrictive pulmonary function that is very common in SCA (Hijazi et al, 2005, Sylvester et al, 2004). Resting systolic pressure was found normal in this SCA group but diastolic pressure was lower than the control group. Low diastolic pressure is frequent in SCA and is presumably the consequence of the peripheral vasodilation and decreased cardiac afterload (Grell et al, 1981, Serjeant \& Serjeant 2001). Although works done in SCA reported higher resting HR in this population compared with control population (Alpert et al, 1981), we found no difference between our two groups at rest. The reason could lie in the fact that baseline HR was measured in supine position. Despite this lack of difference, we found higher CI in SCA patients than in the control group because SV was widely increased in the former group. This 
result is in agreement with previous studies showing that SV is usually markedly increased in SCA (Lonsdorfer et al, 1983). In summary, baseline lung and cardiac function, hematological and hemorheological profile of SCA patients of the present study reflect the profile generally described for most of the SCA patients when they are clinically monitored at rest and in steady-state condition.

Studies that focused on blood rheology demonstrate that at the initial phase of a painful crisis there is a decrease in $\mathrm{RBC}$ deformability and an increase in the number of dense cells (Ballas \& Smith 1992). This is followed with a gradual rebound increase in RBC deformability to levels that are higher than the steady state values and a decrease in the number of dense cells as the crisis resolves. Although hemorheological parameters can not fully explain or predict the occurrence of vaso-occlusive crisis, several studies have observed that when a vasoocclusive event occurs, there is a strong rise in blood viscosity (Awodu et al, 2009, Charache et al, 1982, Richardson et al, 1979, Stuart \& Johnson 1987) in relationship with other biological changes such as an increase in plasma viscosity and fibrinogen concentration and/or a decrease in RBC deformability. Indeed, the measurement of blood viscosity may be a witness of the other biological changes occurring during vaso-occlusion. Physical exercise can induce metabolic/physiological changes such as lactic acid production, hypoxia and hyperthermia, which may promote the polymerization of $\mathrm{HbS}$, and in turn sickling. It is therefore difficult for physicians to recommend physical activity in SCA patients.

As suggested by the heart rate and ventilation values during and at the end of submaximal exercise, the effort proposed in the present study may be considered as very mild (3-4 METs) for control group and mild to moderate for SCA patients: it reflects what can presumably happen in the daily life of SCA patients; i.e. working or exercising at the same absolute submaximal intensity than healthy population. The higher heart rate increase found in SCA group during exercise is not surprising since the same absolute exercise intensity (43 $\pm 6 \mathrm{~W}$ ) 
appeared to be harder for SCA group (48 $\pm 1 \%$ of their Ppeak) than for the control group (30 $\pm 1 \%$ of their Ppeak). In addition, the greater heart rate response may also be interpreted as a physiological adaptation to compensate for the decreased blood oxygen transport capacity related to anemia (i.e. low Hct and $\mathrm{Hb}$ levels) and lower $\mathrm{SpO}_{2}$. Despite these hemodynamic adjustments, SCA group exhibited a significant increase in the blood lactate level at the end of exercise. Although a blood lactate level reflects the balance between lactic acid production and removal at exercise, the greater blood lactate concentration usually found in SCA and other anemia at exercise is usually interpreted as the consequence of a greater anaerobic contribution to exercise (Moheeb et al, 2007). The ventilation data obtained during the submaximal exercise strengthen this hypothesis. Although the first phase of VE kinetic was similar in the two groups and indicated that exercise adaptation during the first minutes was not different between SCA patients and the control group, the pattern of the second phase was strictly different between the two groups. The control group exhibited a plateau suggesting that ventilation is well adapted to the need of exercise in this group. However, the SCA groups exhibited a second phase indicating that ventilation does not adapt as well as in the control group during exercise. Indeed, SCA patients probably exercised around or slightly above their anaerobic threshold (Nery et al, 1982). Ventilation during this second phase is widely dependent on the production of carbon dioxide (Casaburi et al, 1989, Nery et al, 1982). Since the SCA group had an excess of lactate at the end of exercise, it can be hypothesized that carbon dioxide production was also higher in this group as a consequence of the buffering of accumulated hydrogen ion by bicarbonates. Indeed, the newly formed carbon dioxide, as well as the remaining hydrogen ion, could have stimulated ventilation to a greater extent in SCA group, notably at the level of peripheral chemoreceptors such as the carotid ones (Nery et al, 1982). The higher ventilatory strain in SCA patients suggests lower ventilatory efficiency in this group than in the control group for an exercise bout performed at 
40-45 W only. Indeed, one may conclude that the low Ppeak determined during the incremental test, and the greater heart rate, ventilation and blood lactate responses during the submaximal exercise test in the SCA group confirm previous findings showing that SCA patients have usually a limited exercise capacity (Callahan et al, 2002, Delclaux et al, 2005). The presence of anemia and abnormalities in lung function probably participate in the limited exercise capacity of SCA patients (Callahan et al, 2002). Nevertheless, although all the SCA patients exercised at a higher metabolic level than control group, none of them complain of any difficulty during the whole test and none of them exhibited clinical or ECG signs of complication. Indeed, although exercise tolerance is reduced in SCA patients, it seems that they can safely practice at such an intensity level.

These metabolic changes could explain the observed alterations in the proportion of intermediary dense cells and ISCs after exercise in the SCA group. As expected (Ballas \& Mohandas 2004, Ballas \& Smith 1992) patients with SCA had higher proportions of intermediary dense cells and ISCs than the control group at rest, as well as a higher RBC rigidity, which explain their higher corrected blood viscosity. Exercise increased the proportion of ISCs in SCA patients and, as a consequence, decreased the proportion of intermediary dense cells. The lack of change in MCHC in SCA group after exercise despite the fact that ISCs increased could seem surprising. However, hematological counters often fail to detect the increased MCHC of the most dense cells because ISCs are incapable of undergoing the sphering that should occur before measurement of RBC hematological variables by these instruments (Bain 2006). The intermediary dense cells are relatively more deformable than ISCs and, hence, are more likely to adhere to vascular endothelium and initiate the process of vasoocclusion. Since the percent of this cell subpopulation decreased with exercise, one could suggest that the risks for triggering vaso-occlusion could be reduced in SCA patients at the end of the effort. ISCs, in contrast, are rigid cells not capable of 
establishing contact points with vascular endothelium to cause vaso-occlusion and, hence, are more likely to hemolyze intravascularly (Kaul \& Nagel 1993). The formation of ISCs results from the loss of solute and water through specific pathways (Brugnara et al, 2003) and might be the direct consequence of the increase in the blood lactate concentration leading to cellular acidification. As initially proposed by Smith et al. (Smith et al, 1997), the excessive uptake of lactate and hydrogen by RBCs may promote cells dehydration via the activation of the $\mathrm{pH}$ dependent $\mathrm{K}^{+} / \mathrm{Cl}^{-}$co-transporter. In addition, mechanical impairment of the cytoskeleton following repeated sickling cycles could have participated in ISC formation (Nash et al, 1984). The increased number of dehydrated cells in blood is usually interpreted as a risk factor for microvascular disorders in SCA, and therefore one could suggest that the risk for mechanical occlusion of microcirculation could be increased at the end of exercise. However, the decrease in the percent of the most adherent cells (i.e. intermediary dense cells) could have compensated the adverse microcirculatory effects of the increased ISCs percent. Moreover, as recently underlined by Hebbel (Hebbel 2011), the percent of ISCs may widely fluctuate for a given SCA patient, even if the patient remains in clinical steady-state condition. That indicates that the measurement of ISCs in SCA patients is not sufficient to predict the occurrence of a vaso-occlusive event. In addition, calculation of the index of red blood cell rigidity demonstrated that overall $\mathrm{RBC}$ deformability was not widely affected in SCA patients after exercise, as well as after 20 minutes of recovery. This lack of change could seem surprising but analysis of the whole percent of dense RBCs population (intermediary dense cells + ISCs) shown that it does not differ between rest and the end of exercise: the whole percent remains very stable at $40 \%$. Indeed, the risk for mechanical occlusion by poor deformable RBCs after exercise seems to be, finally, of same level than before exercise.

Whole $\eta b$ determined at high shear rate, as it is the case in the present study, is mainly dependant on Hct, $\eta p$, the ability of RBCs to deform and, to a lesser extent, on the number of 
WBC (Baskurt et al, 2009). Although the proportion of ISCs increased at exercise, as well as the total number of $\mathrm{WBC}$, the consequences of these changes on the whole $\eta \mathrm{b}$ of SCA patients was not very pronounced since, as for the control group, we observed no statistical change in uncorrected $\eta \mathrm{b}$ after exercise as compared with baseline (non-significant increase of uncorrected $\eta \mathrm{b}$ of $4.3 \%(\mathrm{p}=0.15)$ and $2.7 \%(\mathrm{p}=0.34)$ at $45 \mathrm{~s}^{-1}$ and $90 \mathrm{~s}^{-1}$, respectively). This $4.3 \%$ increase in whole $\eta \mathrm{b}$ is by far less than the $15-20 \%$ increase previously observed in sickle trait carriers (Tripette et al, 2007) or athletes with hypoxemia (Connes et al, 2004) submitted to intense exercise. As described above, the sum of the proportion of intermediary dense cells and ISCs in SCA group remained unchanged at the end of exercise as compared with resting value, and Hct and $\mathrm{Tk}$ did not change with exercise; these phenomena have played a role in the lack of significant change in $\eta b$. In addition, the other hematological, hemorheological and biochemical parameters exhibited very mild changes ( $\eta p$ ) or no modification at all $\left(\mathrm{Hb}, \mathrm{Na}^{+}, \mathrm{K}^{+}\right.$, prothrombin time or fibrinogen) with exercise. Nevertheless, WBC number slightly increased with exercise in the SCA group. This observation has already been reported by numerous groups in healthy subjects (Shek \& Shephard 1998) and indicates the presence of a slight inflammatory response and/or WBC recruitment from marginal pool following the catecholaminergic stress of exercise (Yalcin et al, 2003). Although, the increase of WBC number did not impact on the whole $\eta b$, one could suggest the presence of a greater risk for vaso-occlusive event after exercise since WBC are highly involved in the pathophysiological mechanisms of vaso-occlusion (Okpala 2006). However, the 10\% WBC increase observed in SCA patients is far by less the increase observed in healthy subjects $(+43 \%)$ or sickle cell trait carriers $(+47 \%)$ after a 15 minutes moderate exercise performed slightly above the first ventilatory threshold (Tripette et al, 2010). Of importance, no subject experienced vaso-occlusive crisis or complained of any pain during and after exercise and within the 3 days of follow-up. Thus, despite the increase of ISCs proportion after exercise 
and the slight increase in WBC number, the physical effort proposed seems to be well tolerated and the hemorheological, hematological and biochemical disturbances remained very mild and probably of insufficient magnitude to trigger vaso-occlusion.

In conclusion, the present study suggested that mild-moderate exercise corresponding to $50 \%$ of the Ppeak of SCA patients is not very harmful for them. Although the physiological exercise tolerance is reduced in SCA patients as compared with the control group, the hemorheological and hematological changes are very mild, except for the formation of ISCs and the slight increase in WBCs count. However, no clinical sign of medical complication was present in any of the patients. We propose that the analysis of several biological factors, such as blood rheology, as well as inflammatory and hemolysis markers, could be necessary to clearly assess the risk for vaso-occlusive crisis at exercise in each SCA patient. Although the exercise proposed in the present study seems to be fairly safe, higher intensity or longer duration could promote greater metabolic changes and dehydration that could be very harmful for this population. Our results constitute a preliminary step and further studies are clearly warranted to test other exercise modalities and to find the most appropriate one, from a risk/benefit balance point of view. The present work can be considered as a first step in that way. 


\begin{abstract}
Aknowledgments
The experiment has been funded by the Agence Universitaire de la Francophonie (AUF). The authors would like to thank all the patients and subjects who kindly accepted to participate to the study. This work is dedicated to Pr Amadou Sangare ${ }^{\dagger}$.

The authors declare no conflic of interest.
\end{abstract}




\section{References}

Alameri, H.F., Aleem, A., Kardas, W., Jehangir, A., Owais, M. \& Al-Momen, A. (2008) Dyspnea, pulmonary function and exercise capacity in adult Saudi patients with sickle cell disease. Saudi Med J, 29, 707-713.

Alcorn, R., Bowser, B., Henley, E.J. \& Holloway, V. (1984) Fluidotherapy and exercise in the management of sickle cell anemia. A clinical report. Phys Ther, 64, 1520-1522.

Alpert, B.S., Gilman, P.A., Strong, W.B., Ellison, M.F., Miller, M.D., McFarlane, J. \& Hayashidera, T. (1981) Hemodynamic and ECG responses to exercise in children with sickle cell anemia. Am J Dis Child, 135, 362-366.

Anthi, A., Machado, R.F., Jison, M.L., Taveira-Dasilva, A.M., Rubin, L.J., Hunter, L., Hunter, C.J., Coles, W., Nichols, J., Avila, N.A., Sachdev, V., Chen, C.C. \& Gladwin, M.T. (2007) Hemodynamic and functional assessment of patients with sickle cell disease and pulmonary hypertension. Am J Respir Crit Care Med, 175, 1272-1279.

Awodu, O.A., Famodu, A.A., Ajayi, O.I., Enosolease, M.E., Olufemi, O.Y. \& Olayemi, E. (2009) Using serial haemorheological parameters to assess clinical status in sickle cell anaemia patients in vaso-occlussive crisis. Clin Hemorheol Microcirc, 41, 143-148.

Bain, B.J. (2006) Blood cells: a practical guide (Wiley-Blackwell). Fourth Edition.

Balducci, S., Zanuso, S., Fernando, F., Fallucca, S., Fallucca, F. \& Pugliese, G. (2009) Physical activity/exercise training in type 2 diabetes. The role of the Italian Diabetes and Exercise Study. Diabetes Metab Res Rev, 25 Suppl 1, S29-33.

Ballas, S.K., Larner, J., Smith, E.D., Surrey, S., Schwartz, E. \& Rappaport, E.F. (1988) Rheologic predictors of the severity of the painful sickle cell crisis. Blood, 72, 12161223.

Ballas, S.K. \& Mohandas, N. (2004) Sickle red cell microrheology and sickle blood rheology. Microcirculation, 11, 209-225.

Ballas, S.K. \& Smith, E.D. (1992) Red blood cell changes during the evolution of the sickle cell painful crisis. Blood, 79, 2154-2163.

Baskurt, O.K., Boynard, M., Cokelet, G.C., Connes, P., Cooke, B.M., Forconi, S., Liao, F., Hardeman, M.R., Jung, F., Meiselman, H.J., Nash, G., Nemeth, N., Neu, B., Sandhagen, B., Shin, S., Thurston, G. \& Wautier, J.L. (2009) New guidelines for hemorheological laboratory techniques. Clin Hemorheol Microcirc, 42, 75-97.

Belcher, J.D., Marker, P.H., Weber, J.P., Hebbel, R.P. \& Vercellotti, G.M. (2000) Activated monocytes in sickle cell disease: potential role in the activation of vascular endothelium and vaso-occlusion. Blood, 96, 2451-2459.

Callahan, L.A., Woods, K.F., Mensah, G.A., Ramsey, L.T., Barbeau, P. \& Gutin, B. (2002) Cardiopulmonary responses to exercise in women with sickle cell anemia. $\mathrm{Am} J$ Respir Crit Care Med, 165, 1309-1316.

Casaburi, R., Barstow, T.J., Robinson, T. \& Wasserman, K. (1989) Influence of work rate on ventilatory and gas exchange kinetics. J Appl Physiol, 67, 547-555.

Charache, S., de la Monte, S. \& MacDonald, V. (1982) Increased blood viscosity in a patient with sickle cell anemia. Blood Cells, 8, 103-109.

Chong, S.S., Boehm, C.D., Higgs, D.R. \& Cutting, G.R. (2000) Single-tube multiplex-PCR screen for common deletional determinants of alpha-thalassemia. Blood, 95, 360-362.

Colberg, S.R. \& Grieco, C.R. (2009) Exercise in the treatment and prevention of diabetes. Curr Sports Med Rep, 8, 169-175.

Connes, P. (2010) Hemorheology and exercise: effects of warm environments and potential consequences for sickle cell trait carriers. Scand J Med Sci Sports, 20 Suppl 3, 48-52. 
Connes, P., Bouix, D., Durand, F., Kippelen, P., Mercier, J., Prefaut, C., Brun, J.F. \& Caillaud, C. (2004) Is hemoglobin desaturation related to blood viscosity in athletes during exercise? Int J Sports Med, 25, 569-574.

Connes, P., Hue, O., Tripette, J. \& Hardy-Dessources, M.D. (2008) Blood rheology abnormalities and vascular cell adhesion mechanisms in sickle cell trait carriers during exercise. Clin Hemorheol Microcirc, 39, 179-184.

Connes, P., Machado, R., Hue, O. \& Reid, H. (2010) Sickle cell anemia. In Exercise physiology: from a cellular approach to an integrative approach. Connes $P$, Hue $O$ and Perrey S. IOS press (Amsterdam, Berlin, Tokyo, Washington DC), 607-622.

Craft, L.L. \& Perna, F.M. (2004) The Benefits of Exercise for the Clinically Depressed. Prim Care Companion J Clin Psychiatry, 6, 104-111.

Danon, D. \& Marikovsky, V. (1964) Determination of Density Distribution of Red Cell Population. J Lab Clin Med, 64, 668-674.

Delclaux, C., Zerah-Lancner, F., Bachir, D., Habibi, A., Monin, J.L., Godeau, B. \& Galacteros, F. (2005) Factors associated with dyspnea in adult patients with sickle cell disease. Chest, 128, 3336-3344.

Dintenfass, L. (1985) Red cell rigidity, "Tk", and filtration. Clin Hemorheol, 5, 241-244.

Dubach, P., Sixt, S. \& Myers, J. (2001) Exercise training in chronic heart failure: why, when and how. Swiss Med Wkly, 131, 510-514.

Durpes, M.C., Nebor, D., du Mesnil, P.C., Mougenel, D., Decastel, M., Elion, J. \& HardyDessources, M.D. (2010) Effect of interleukin-8 and RANTES on the Gardos channel activity in sickle human red blood cells: role of the Duffy antigen receptor for chemokines. Blood Cells Mol Dis, 44, 219-223.

Gladwin, M.T., Schechter, A.N., Ognibene, F.P., Coles, W.A., Reiter, C.D., Schenke, W.H., Csako, G., Waclawiw, M.A., Panza, J.A. \& Cannon, R.O., 3rd (2003) Divergent nitric oxide bioavailability in men and women with sickle cell disease. Circulation, 107, 271-278.

Grell, G.A., Alleyne, G.A. \& Serjeant, G.R. (1981) Blood pressure in adults with homozygous sickle cell disease. Lancet, 2, 1166.

Hackney, A.C., Hezier, W., Gulledge, T.P., Jones, S., Strayhorn, D., Busby, M., Hoffman, E. \& Orringer, E.P. (1997) Effects of hydroxyurea administration on the body weight, body composition and exercise performance of patients with sickle-cell anaemia. Clin Sci (Lond), 92, 481-486.

Hebbel, R.P. (1997) Perspectives series: cell adhesion in vascular biology. Adhesive interactions of sickle erythrocytes with endothelium. J Clin Invest, 99, 2561-2564.

Hebbel, R.P. (2011) Reconstructing sickle cell disease: a data-based analysis of the "hyperhemolysis paradigm" for pulmonary hypertension from the perspective of evidence-based medicine. Am J Hematol, 86, 123-154.

Hijazi, Z., Onadeko, B.O., Khadadah, M., Haider, M.Z., Adekile, A.D. \& Al-Habashi, H. (2005) Pulmonary function studies in Kuwaiti children with sickle cell disease and elevated $\mathrm{Hb}$ F. Int J Clin Pract, 59, 163-167.

Hurkmans, E., van der Giesen, F.J., Vliet Vlieland, T.P., Schoones, J. \& Van den Ende, E.C. (2009) Dynamic exercise programs (aerobic capacity and/or muscle strength training) in patients with rheumatoid arthritis. Cochrane Database Syst Rev, CD006853.

Jama, A.H., Salem, A.H. \& Dabbous, I.A. (2002) Massive splenic infarction in Saudi patients with sickle cell anemia: a unique manifestation. Am J Hematol, 69, 205-209.

Kaul, D.K. \& Nagel, R.L. (1993) Sickle cell vasoocclusion: many issues and some answers. Experientia, 49, 5-15.

Kenny, M.W., George, A.J. \& Stuart, J. (1980) Platelet hyperactivity in sickle-cell disease: a consequence of hyposplenism. J Clin Pathol, 33, 622-625. 
Keslacy, S., Carra, J. \& Ramonatxo, M. (2008) Role of respiratory system impedance in the difference of ventilatory control between children and adults. Respir Physiol Neurobiol, 161, 239-245.

Key, N.S., Slungaard, A., Dandelet, L., Nelson, S.C., Moertel, C., Styles, L.A., Kuypers, F.A. \& Bach, R.R. (1998) Whole blood tissue factor procoagulant activity is elevated in patients with sickle cell disease. Blood, 91, 4216-4223.

Kouidi, E.J. (2001) Central and peripheral adaptations to physical training in patients with end-stage renal disease. Sports Med, 31, 651-665.

Leslie, J., Langler, D., Serjeant, G.R., Serjeant, B.E., Desai, P. \& Gordon, Y.B. (1975) Coagulation changes during the steady state in homozygous sickle-cell disease in Jamaica. Br J Haematol, 30, 159-166.

Lonsdorfer, J., Bogui, P., Otayeck, A., Bursaux, E., Poyart, C. \& Cabannes, R. (1983) Cardiorespiratory adjustments in chronic sickle cell anemia. Bull Eur Physiopathol Respir, 19, 339-344.

Machado, R.F., Mack, A.K., Martyr, S., Barnett, C., Macarthur, P., Sachdev, V., Ernst, I., Hunter, L.A., Coles, W.A., Nichols, J.P., Kato, G.J. \& Gladwin, M.T. (2007) Severity of pulmonary hypertension during vaso-occlusive pain crisis and exercise in patients with sickle cell disease. Br J Haematol, 136, 319-325.

Machado, R.F., Martyr, S., Kato, G.J., Barst, R.J., Anthi, A., Robinson, M.R., Hunter, L., Coles, W., Nichols, J., Hunter, C., Sachdev, V., Castro, O. \& Gladwin, M.T. (2005) Sildenafil therapy in patients with sickle cell disease and pulmonary hypertension. $\mathrm{Br}$ J Haematol, 130, 445-453.

Miller, D.M., Winslow, R.M., Klein, H.G., Wilson, K.C., Brown, F.L. \& Statham, N.J. (1980) Improved exercise performance after exchange transfusion in subjects with sickle cell anemia. Blood, 56, 1127-1131.

Moheeb, H., Wali, Y.A. \& El-Sayed, M.S. (2007) Physical fitness indices and anthropometrics profiles in schoolchildren with sickle cell trait/disease. Am J Hematol, 82, 91-97.

Nery, L.E., Wasserman, K., Andrews, J.D., Huntsman, D.J., Hansen, J.E. \& Whipp, B.J. (1982) Ventilatory and gas exchange kinetics during exercise in chronic airways obstruction. J Appl Physiol, 53, 1594-1602.

Okpala, I. (2006) Leukocyte adhesion and the pathophysiology of sickle cell disease. Curr Opin Hematol, 13, 40-44.

Okpala, I., Daniel, Y., Haynes, R., Odoemene, D. \& Goldman, J. (2002) Relationship between the clinical manifestations of sickle cell disease and the expression of adhesion molecules on white blood cells. Eur J Haematol, 69, 135-144.

Pianosi, P., D'Souza, S.J., Charge, T.D., Esseltine, D.E. \& Coates, A.L. (1993) Pulmonary function abnormalities in childhood sickle cell disease. J Pediatr, 122, 366-371.

Platt, O.S. (1982) Exercise-induced hemolysis in sickle cell anemia: shear sensitivity and erythrocyte dehydration. Blood, 59, 1055-1060.

Richardson, S.G., Matthews, K.B., Stuart, J., Geddes, A.M. \& Wilcox, R.M. (1979) Serial changes in coagulation and viscosity during sickle-cell crisis. Br J Haematol, 41, 95103.

Serjeant, B.E., Mason, K.P., Kenny, M.W., Stuart, J., Higgs, D.R., Weatherall, D.J., Hayes, R.J. \& Serjeant, G.R. (1983) Effect of alpha thalassaemia on the rheology of homozygous sickle cell disease. Br J Haematol, 55, 479-486.

Serjeant, G.R. \& Serjeant, B.E. (2001) Sickle cell disease (Oxford Medical Publications). Third Edition.

Shek, P.N. \& Shephard, R.J. (1998) Physical exercise as a human model of limited inflammatory response. Can J Physiol Pharmacol, 76, 589-597. 
Smith, J.A., Telford, R.D., Kolbuch-Braddon, M. \& Weidemann, M.J. (1997) Lactate/H+ uptake by red blood cells during exercise alters their physical properties. Eur J Appl Physiol Occup Physiol, 75, 54-61.

Stuart, J. \& Johnson, C.S. (1987) Rheology of the sickle cell disorders. Baillieres Clin Haematol, 1, 747-775.

Sylvester, K.P., Patey, R.A., Milligan, P., Dick, M., Rafferty, G.F., Rees, D., Thein, S.L. \& Greenough, A. (2004) Pulmonary function abnormalities in children with sickle cell disease. Thorax, 59, 67-70.

Sylvester, K.P., Patey, R.A., Rafferty, G.F., Rees, D., Thein, S.L. \& Greenough, A. (2007) Airway hyperresponsiveness and acute chest syndrome in children with sickle cell anemia. Pediatr Pulmonol, 42, 272-276.

Tripette, J., Alexy, T., Hardy-Dessources, M.D., Mougenel, D., Beltan, E., Chalabi, T., Chout, R., Etienne-Julan, M., Hue, O., Meiselman, H.J. \& Connes, P. (2009) Red blood cell aggregation, aggregate strength and oxygen transport potential of blood are abnormal in both homozygous sickle cell anemia and sickle-hemoglobin $\mathrm{C}$ disease. Haematologica, 94, 1060-1065.

Tripette, J., Connes, P., Beltan, E., Chalabi, T., Marlin, L., Chout, R., Baskurt, O.K., Hue, O. \& Hardy-Dessources, M.D. (2010) Red blood cell deformability and aggregation, cell adhesion molecules, oxidative stress and nitric oxide markers after a short term, submaximal, exercise in sickle cell trait carriers. Clin Hemorheol Microcirc, 45, 3952.

Tripette, J., Hardy-Dessources, M.D., Sara, F., Montout-Hedreville, M., Saint-Martin, C., Hue, O. \& Connes, P. (2007) Does repeated and heavy exercise impair blood rheology in carriers of sickle cell trait? Clin J Sport Med, 17, 465-470.

Welsh, L., Kemp, J.G. \& Roberts, R.G. (2005) Effects of physical conditioning on children and adolescents with asthma. Sports Med, 35, 127-141.

Yalcin, O., Erman, A., Muratli, S., Bor-Kucukatay, M. \& Baskurt, O.K. (2003) Time course of hemorheological alterations after heavy anaerobic exercise in untrained human subjects. J Appl Physiol, 94, 997-1002.

Young, R.C., Jr., Rachal, R.E., Reindorf, C.A., Armstrong, E.M., Polk, O.D., Jr., Hackney, R.L., Jr. \& Scott, R.B. (1988) Lung function in sickle cell hemoglobinopathy patients compared with healthy subjects. J Natl Med Assoc, 80, 509-514. 
Table 1: Baseline cardiac and spirometric parameters measured at rest in the control group and SCA group

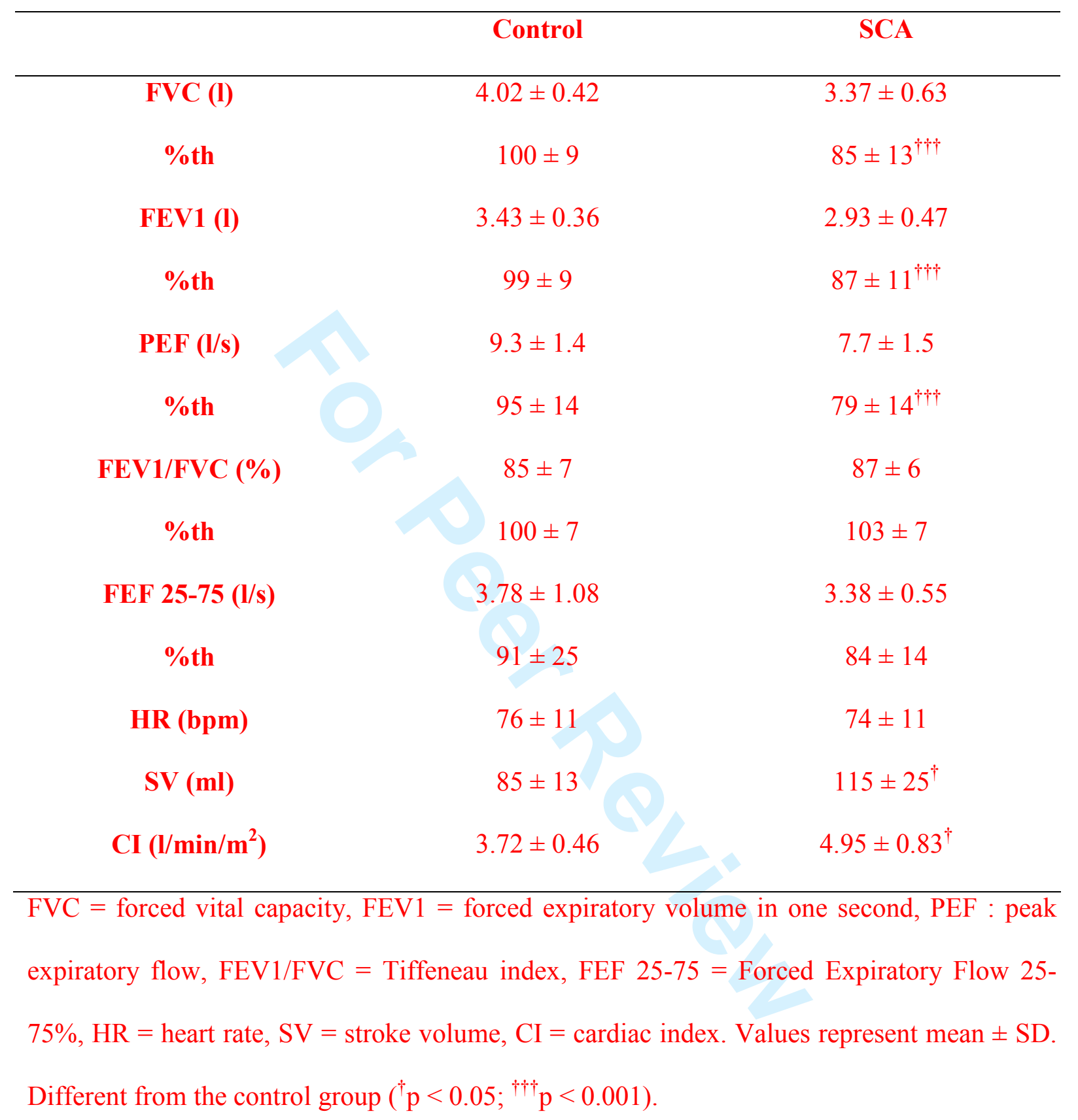


Table 2: Hematological and hemorheological parameters in the control and SCA group at rest and at the end of exercise.

\begin{tabular}{|c|c|c|c|c|c|c|}
\hline & \multicolumn{3}{|c|}{ Control } & \multicolumn{3}{|c|}{ SCA } \\
\hline & Rest & Exercise & 20 minutes & Rest & Exercise & 20 minutes \\
\hline & & & recovery & & & recovery \\
\hline $\mathrm{Hb}(\mathrm{g} / \mathrm{dL})$ & $14.6 \pm 1.4$ & $14.7 \pm 1.1$ & - & $8.9 \pm 1.8^{\text {ரो }}$ & $9.1 \pm 1.7^{\dagger \dagger}$ & - \\
\hline Het $(\%)$ & $44.0 \pm 1.9$ & $44.3 \pm 2.8$ & $44.0 \pm 2.4$ & $23.9 \pm 3.2^{\dagger \dagger \dagger}$ & $24.9 \pm 3.4^{\dagger \dagger \dagger}$ & $24.2 \pm 3.3^{\dagger \dagger \dagger}$ \\
\hline $\operatorname{RBC}\left(10^{12} / \mathrm{l}\right)$ & $5.0 \pm 0.5$ & $5.0 \pm 0.5$ & - & $3.0 \pm 0.6^{\dagger \dagger \dagger}$ & $3.1 \pm 0.6^{\dagger \dagger \dagger}$ & - \\
\hline WBC $\left(10^{9} / 1\right)$ & $4.2 \pm 1.2$ & $4.5 \pm 1.1$ & - & $10.3 \pm 2.2^{\dagger \dagger \dagger}$ & $11.3 \pm 2.5^{* \dagger \dagger}$ & - \\
\hline $\operatorname{PLT}\left(10^{9} / 1\right)$ & $178 \pm 70$ & $189 \pm 58$ & - & $302 \pm 117^{\dagger \dagger \dagger}$ & $342 \pm 74^{\dagger \dagger \dagger}$ & - \\
\hline MCV (fl) & $84.8 \pm 5.2$ & $84.4 \pm 5.3$ & - & $89.2 \pm 10.8$ & $89.0 \pm 11.5$ & - \\
\hline MCHC (g/dl) & $33.9 \pm 0.7$ & $33.9 \pm 0.6$ & - & $34.2 \pm 1.0$ & $33.9 \pm 0.9$ & - \\
\hline Native $\eta \mathrm{b}$ at $45 \mathrm{~s}^{-1}(\mathrm{mPa} / \mathrm{s})$ & $5.72 \pm 0.39$ & $5.68 \pm 0.56$ & $5.51 \pm 0.60$ & $4.64 \pm 0.28^{\dagger \dagger}$ & $4.84 \pm 0.33^{\dagger \dagger}$ & $4.76 \pm 0.30^{\dagger \dagger}$ \\
\hline Native $\eta b$ at $90 \mathrm{~s}^{-1}(\mathrm{mPa} / \mathrm{s})$ & $5.41 \pm 0.42$ & $5.31 \pm 0.55$ & $5.13 \pm 0.56$ & $4.36 \pm 0.26^{\dagger \dagger}$ & $4.48 \pm 0.28^{\dagger \dagger \dagger}$ & $4.45 \pm 0.29^{\dagger \dagger}$ \\
\hline Corrected $\eta b$ at $45 \mathrm{~s}^{-1}(\mathrm{mPa} / \mathrm{s})$ & $5.15 \pm 0.20$ & $5.18 \pm 0.24$ & $5.05 \pm 0.33$ & $5.58 \pm 0.39^{\dagger \dagger \dagger}$ & $5.70 \pm 0.41^{\dagger \dagger \dagger}$ & $5.72 \pm 0.39^{\dagger \dagger}$ \\
\hline Corrected $\eta b$ at $90 \mathrm{~s}^{-1}(\mathrm{mPa} / \mathrm{s})$ & $4.89 \pm 0.20$ & $4.87 \pm 0.23$ & $4.77 \pm 0.35$ & $5.29 \pm 0.38^{\dagger \dagger \dagger}$ & $5.38 \pm 0.44^{\dagger \dagger \dagger}$ & $5.42 \pm 0.39^{\dagger \dagger}$ \\
\hline$\eta \mathbf{p}(\mathrm{mPa} / \mathbf{s})$ & $1.20 \pm 0.07$ & $1.26 \pm 0.06^{*}$ & $1.24 \pm 0.07$ & $1.20 \pm 0.07$ & $1.28 \pm 0.10^{* *}$ & $1.20 \pm 0.08$ \\
\hline
\end{tabular}




\begin{tabular}{|c|c|c|c|c|c|c|}
\hline Tk & $0.96 \pm 0.06$ & $0.91 \pm 0.05$ & $0.91 \pm 0.05$ & $1.57 \pm 0.16^{1+\dagger}$ & $1.47 \pm 0.19^{\dagger \dagger \dagger}$ & $1.55 \pm 0.16^{\dagger \dagger \dagger}$ \\
\hline Intermediary dense cells (\%) & $12.2 \pm 11.4$ & $12.1 \pm 13.8$ & - & $28.6 \pm 8.9^{\dagger \dagger \dagger}$ & $20.6 \pm 13.1^{*}$ & - \\
\hline Cells with density $>1.120(\%)$ & $0.4 \pm 1.3$ & $0.5 \pm 1.0$ & - & $11.4 \pm 12.9^{\dagger \dagger}$ & $18.3 \pm 13.7 * * \dagger \dagger$ & - \\
\hline
\end{tabular}

$\overline{\mathrm{RBC}}=$ red blood cell count, $\mathrm{WBC}=$ white blood cell count, $\mathrm{PLT}=$ platelet count, $\mathrm{MCV}=$ mean cell volume, $\mathrm{MCHC}=$ mean corpuscular hemoglobin concentration, $\eta \mathrm{b}=$ blood viscosity, $\eta p=$ plasma viscosity, $\mathrm{Tk}=$ index of RBC rigidity. Hemorheological parameters $(\eta \mathrm{b}, \eta p, \mathrm{Tk})$ and Hct have been determined at 20 minutes recovery too. Values represent mean \pm SD. Different from rest $\left({ }^{*} \mathrm{p}<0.05 ; * * \mathrm{p}<0.01\right) ;$ different from the control group $\left({ }^{\dagger \dagger} \mathrm{p}<0.01 ;{ }^{\dagger \dagger} \mathrm{p}<0.001\right)$ 
Table 3: Biochemical parameters in the control and SCA group at rest and at the end of exercise.

\begin{tabular}{ccccc}
\hline & \multicolumn{2}{c}{ Control } & \multicolumn{2}{c}{ SCA } \\
\hline & Rest & Exercise & Rest & Exercise \\
\hline $\mathbf{N a}^{+}(\mathbf{m M})$ & $143 \pm 4$ & $143 \pm 4$ & $139 \pm 5^{\dagger}$ & $140 \pm 4$ \\
$\mathbf{K}^{+}(\mathbf{m M})$ & $4.0 \pm 0.7$ & $3.9 \pm 0.4$ & $3.9 \pm 0.6$ & $3.9 \pm 0.4$ \\
Prothrombin time (\%) & $84 \pm 13$ & $85 \pm 10$ & $78 \pm 10$ & $78 \pm 13$ \\
Fibrinogen (g/L) & $2.6 \pm 0.4$ & $2.6 \pm 0.4$ & $2.7 \pm 0.5$ & $2.6 \pm 0.5$ \\
Lactate $(\mathbf{m M} \mathbf{M})$ & $2.0 \pm 0.8$ & $2.1 \pm 0.9$ & $2.0 \pm 1.0$ & $3.1 \pm 1.7 * \dagger \dagger$ \\
\hline Values represent mean \pm SD. Different & from rest $(* \mathrm{p}<0.05 ;) ;$ different from the control \\
group $\left({ }^{\dagger} \mathrm{p}<0.05 ;{ }^{\dagger \dagger} \mathrm{p}<0.01\right)$ & & &
\end{tabular}


Figure 1: Effects of exercise on heart rate in the control group and SCA group. Different from rest $(* * * \mathrm{p}<0.001)$; different from the control group $\left({ }^{\dagger} \mathrm{p}<0.05\right)$

Figure 2: Effects of exercise on ventilation in the control group and SCA group. Different from rest $(* * * p<0.001)$; different from the control group $\left({ }^{\dagger} \mathrm{p}<0.05\right)$ 


\section{Figure 1}

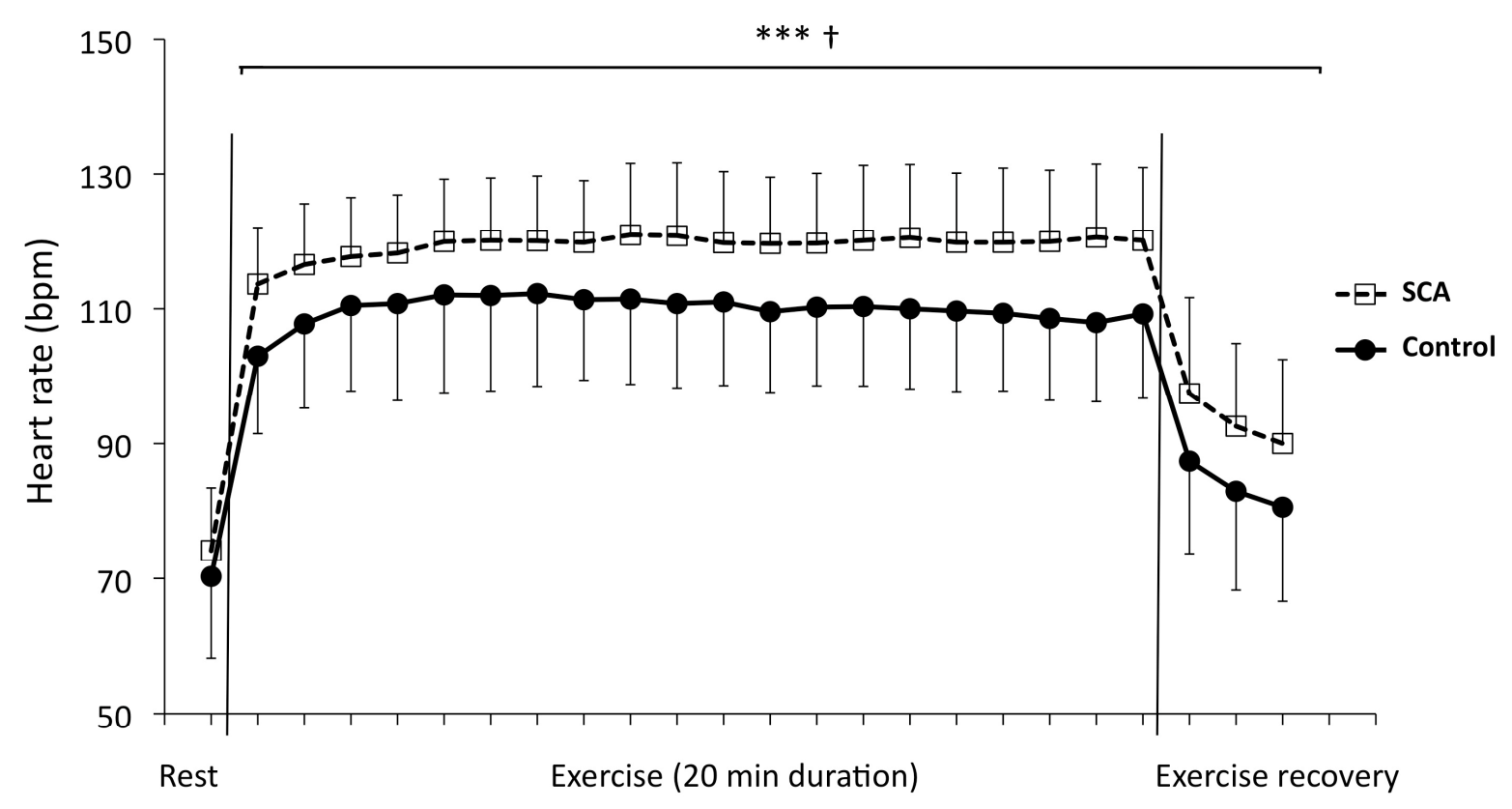


Figure 2

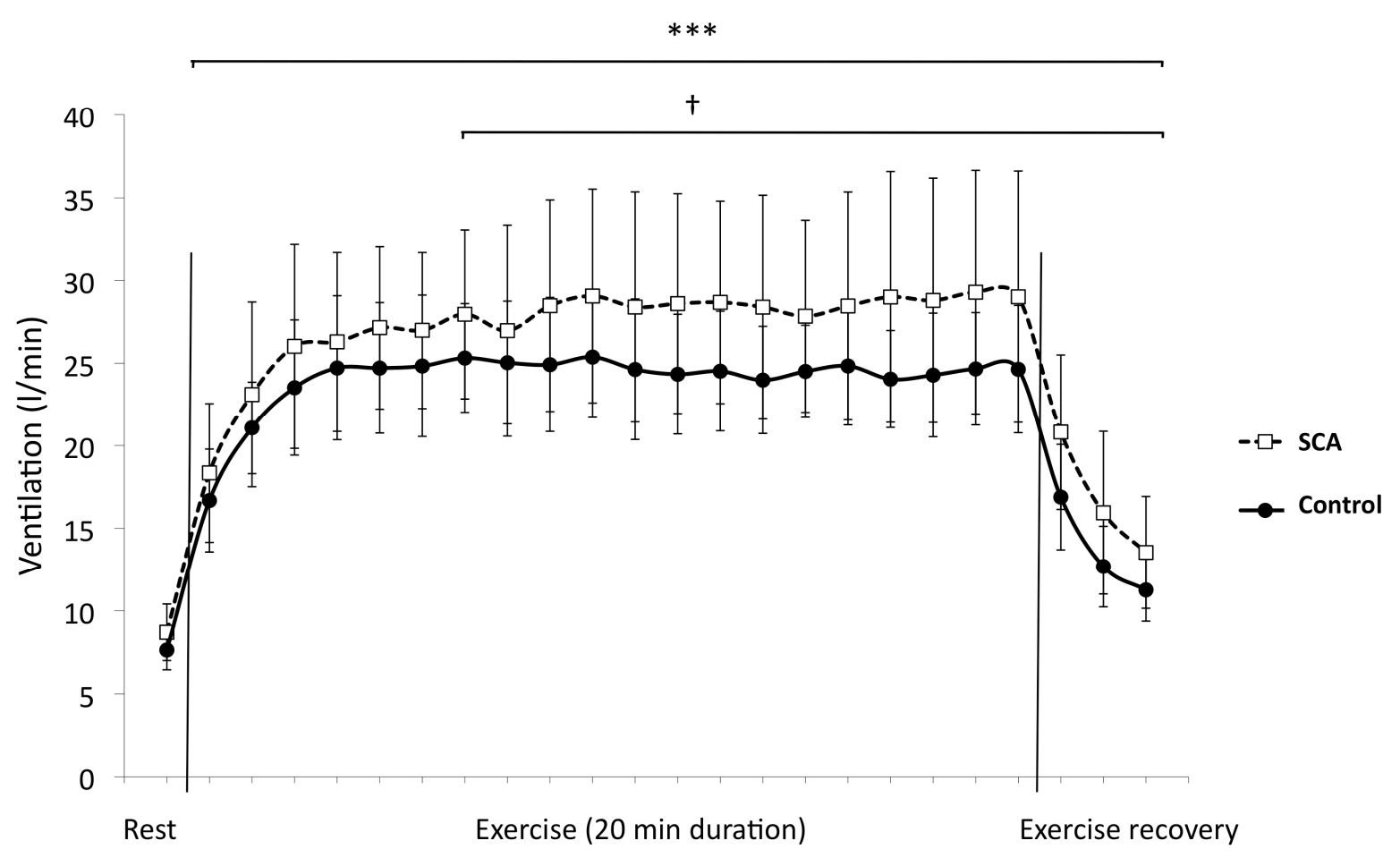

